\title{
Research on Genre-based Teaching Approaches and Teaching Problems of College English Writing
}

\author{
Shaofan Wang \\ College of Foreign Languages \\ North China Electric Power University \\ Baoding, China
}

\begin{abstract}
Starting from analyzing the current condition of college English writing teaching and the problems, this paper analyzes the non-language factor errors of the students in writing process, and proposes the suggestions for improving college English writing teaching using genre-based teaching approaches on the basis of the aforementioned, and summaries its advantages.
\end{abstract}

Keywords-genre; genre-based teaching approaches; nonlanguage factors; writing teaching

\section{INTRODUCTION}

English writing has long been regarded as the difficulty and weak link in English teaching and learning by English teachers and students and also an important means to measure the learners' English level. For most Chinese students, English writing is often affected by two factors: one is the influence of Chinese thinking style, namely, express the Chinese thoughts in English, making the foreigners who don't understand Chinese culture have no idea about the meaning; the other is the influence of composition grade standard of traditional English exam, namely, giving priority to grammar and vocabulary, resulting in that writing is the process of reciting the complete set of sentence pattern and the model essay for most of the students. Mechanical recitation has resulted in students' use of excessive simple sentence, the second person pronouns, function words and conjunctions in writing, with fewer clauses, lexical and semantic cohesion in writing, and colloquial tendency [1][2], etc. At the same time, it is generally believed that the key of the problem lies in teaching methods. The author plans to make initial discussion on how to apply genre-based teaching approaches to college English writing teaching through reviewing the background, essence and comparative advantages of genre-based teaching approaches in combination with his own teaching, scientific research and working practice, expecting to provide a new perspective for college English writing teaching.

\section{CURRENT SituAtion OF COLLEGE ENGLISH Writing TEACHING AND THE PROBLEMS}

\section{A. Teaching Hours}

In public English teaching in colleges, writing is not an independent course, but integrated in the interpretation of

*The project item number 2014MS184 of the basic scientific research business expense of the Central University of North China Electric Power University. reading and writing. Therefore the teaching hours used for writing teaching is limited, and cannot provide students with enough writing opportunities. Even if in the practice prior to examination, it is imitation to the vocabulary, sentence patterns and structure of the recited model essays, without considering the social background and actual communicative purpose of the article.

\section{B. Textbook}

So far, no systematic public English textbook has been published in China. In recent years, the public English textbooks adopted by various colleges and universities mainly include New Horizon College English published by Foreign Language Teaching and Research Press; College English and Experiencing English published by Shanghai Foreign Language Education Press; 21st century English published by Higher Education Press. These textbooks all emphasis to enhance students' comprehensive language ability, yet no one has given specific instructions regarding writing teaching in terms of methods and contents.

\section{Negative effects brought by CET 4 and CET 6 to English Writing}

CET 4 and CET 6 have played a great role in promoting college English teaching since the implementation, and have obtained wide recognition within the society, but they have misled the students' understanding of significance and importance of writing as well as the section of teaching method. Gan Wenping [3] summarizes the failures of CET composition subject as vague description of the outline requirements in Discussion on CET-4 Composition Subject Failures; the order for composition test is different, and composition subject standard is inconsistent; test requirements and scoring criteria are not specific, which has undoubtedly rendered great negative impact on the writing teaching.

\section{Teacher-centered Teaching Mode}

Today, most time of English writing class is still teacher centered, and the cramming teaching makes the class atmosphere boring. Misunderstanding exists in teachers' and students' recognition on how to "teach" and "learn", as they emphasis knowledge imparting, yet neglect ability cultivation and training. Students practice less as teachers speak more. No matter how wonderful the teachers' classes are, students are 
only the containers of knowledge, to passively listen and take notes, and their subjective initiative and creative thinking cannot be given to play in full, forming the situation of "onesided enthusiasm" with teachers' angry and students' confusion. How to change education mode and improve the students' participation are the practical problems need to be considered for current college English writing teaching.

\section{E. Error Types of Students' Writing}

Error types of students' writing mainly reflect in two aspects of language factors and non-language factors.

According to the author's observation in his more than ten years' teaching practice, students' language errors in English writing are mainly in the wording and phrasing and grammar. What's more, some students' writing is not English writing in its true sense, because they just translate the Chinese into English using corresponding English words. If teachers pay attention to the contrast of Chinese and English in terms of language structure in the classroom, students' language error in English writing will be greatly reduced, which is of very important realistic significance for improving English writing level.

But with the improvement of students' comprehensive application level of English, their language errors, such as incorrect spelling, grammatical mistakes, simple sentence pattern will be reduced gradually, but the errors on the level of text caused by non-language factors in terms of overall arrangement, paragraph structure become more and more visible, which are mainly reflected in the following aspects:

1) The article is unfolded in a spiral type: American scholar Kaplan [4] once compared the English articles written by the learners of English and Oriental languages (including mandarin), and found that the organization and development of English text is the "linear type", namely stating the theme directly; yet the Chinese students use "spiral type" structure, namely, approaching the subject without coming straight to the point. The textual pattern of English is a deductive one, which brings the topic, opinions and attitudes into the article from the beginning and then illustrates by facts, that is to say give out the topic sentence first followed by naturally connected example sentences, and then make the conclusion; while the Chinese article belongs to the type of induction, namely talk about the details or examples first, and then gradually leads to the conclusion, finally ended with summary.

The Chinese writing habits formed in the process of while they are receiving modern Chinese education affect Chinese students' English writing directly, because the Chinese writing standard, principle and technique will have direct impact on Chinese students' selection of textual pattern of English writing. However, students have not trained systematically in terms of English textual level, let alone genre analysis and organizing of English article. Fundamentally speaking, the problem of text organization ability lies in thinking itself, yet thinking training is a complicated process which is difficult to get effect instantly. At the same time, the problem also shows that emphasizing grammar and neglecting text is to place the unimportant things before the important ones.
2) Euphemistic hint of article subject: Domestic and foreign scholars discover through research that vague main idea is one of the important problems in Chinese students' English writing. Cai Jigang [5] has constructed the explicit and implicit main idea in English articles as per the genres of argumentation, review, essay and narration, and found that except the treatment of argumentation's main idea is similar to that of English, the main idea of Chinese articles is implicit in most cases, which requires the readers to experience by themselves, and there is rarely or no such cases to express it using just one sentence. Foreign teachers evaluate Chinese students' English writing as there are vague views without distinctive theme.

3) Flashy text strategy: Text strategy is a term proposed by Enkvist [6], referring to the overall decision and choice made by the author against the text according to the communicative purpose, and it is a measurement made on the decision parameters for a certain purpose. Chinese students tend to use the strategies of accumulation and repeated conclusions, citing allusions and authority as well as paraphrasing idioms and proverbs in English writing; while English emphases the using of data and details as well as citing personal experience and that of ordinary person. While summarizing paper inspection of the composition of TEM 4 of 1993, Yang Xiaorong [7] discovered that common problem of Chinese students in the 1993 national level 4 English major education in colleges and universities nationwide examination composition marking found common problem of Chinese students' English writing is that there are too many subjective judgments, declaim and idioms and allusions with few fact arguments, logical reasoning and personal innovation, making the communicative effect of English composition be greatly reduced.

\section{F. No Enough Importance Is Attached to the Scientific and Systematic Qualities of English Writing in Classroom}

English writing has its inherent characteristics and laws, requiring the paragraphs have unity and coherence. Unity requires the paragraph shall have a topic sentence and supporting sentences. Topic sentence describes the main idea of this paragraph and supporting sentences develop this theme, and there is only one main idea in the whole paragraph. Consistency requires the sentences within the paragraph shall be coherent which need to be realized by cohesion technique. Current classroom teaching is just the superficial writing process conducted according to the teaching material writing requirements, which is short of the scientific and systematic writing training in combination with students' actual English level, neglecting the cultivation of students' language ability.

To sum up, how to correct students' writing errors and confused writing thoughts aroused by non-language factors in the process of English writing, how to realize the scientific and systematic English writing teaching by virtue of classroom teaching to achieve the enhancement of teaching quality and efficiency are particularly important for the English teachers. As a result, the author thinks that using "genre-based teaching approaches" to improve college English writing teaching is a good countermeasure to solve these problems. 


\section{THEORETICAL BASIS}

\section{A. Genre}

With the development of text analysis, linguists are no longer satisfied with the analysis of the language itself, and they have a strong interest in the analysis of social and cultural factors of genre. Swales [8] thinks that genre is the product of classifying human's communicative events under certain social and cultural background. The so-called communicative events refer to the examples of human to handle affairs in the society using language according to specific purpose and specific programs. Martin [9] holds the opinion that genre is a kind of communicative purpose oriented social intercourse activity by steps.

Singaporean Bhatia [10] summarizes a definition containing 80 words for genre on the basis of Swales' genre theory. Chinese scholars Qin Xiubai [11], ZhangYuanrong[12], Fang Yan [13] and others have made a systematic summary of the concept of genre according to foreign scholars' different interpretation on genre: 1) any genre is purposeful, and the main criteria to distinguish text genre is a set of communicative purpose generally accepted and followed by the people, not just the common ground of the text in terms of form; 2) examples of language genre can change with its prototype, and the examples belong to the same genre may differ in some respects; 3 ) the theoretical basis of genre has the highly conventional restriction on the text's contents and forms, and people of the same community comply with this kind of conditionality while constructing text; 4) genre consists of several steps with the characteristics of stability, repeatability and habituation; 5) the success of communicative behavior organization partially depends on people's grasp and proficiency degree of genre; 6) genre is closely related to culture, may be one aspect of cultural context; 7) genre and context/register are correlated, and the realization of genre is related to its context/register configuration, and contextual configuration can be used to predict this genre's structure potential, therefore genre has its own schematic structure.

\section{B. Genre Analysis}

Genre analysis not only involves style analysis but also involves text analysis, yet it does not adopt only the language analysis method, but combines the linguistic analysis method with the method of sociology and psychology [14]. Linguistics analysis method is mainly used to describe the language features of the text. Both the style analysis and register analysis have failed to answer a question, namely, why people tend to this kind of wording and phrasing and textual design but not other kinds while people are constructing a certain type of text; sociological approach takes the text as social phenomenon and social behavior to research, explore the sociality and normativity of the text, so as to reveal the social and cultural factors of formation of specific genre structure and the continuing use of it; psychological method mainly researches the text's cognitive structure and constructing strategies, and explore how the specific communicative purpose is realized in the text. Genre analysis goes beyond the simple description of language features, and tries to explain the theoretical basis of text constructing, explores the social and cultural factors and psychological cognitive factors behind the text structure, so as to reveal the special form to achieve communication goal and the normativity of text construction.

\section{Genre-based Teaching Approach}

"Swalesian School" usually takes the move and step as the starting point of text analysis while analyzing the text, and they often take academic and professional writings as the analysis object. Australian School divides the genre into such communicative events as the appointment with dentist, telling stories, job hunting and inviting people to dinner, and analyze the schematic structure of these communicative events with emphasis; in the field of church, they carry out teaching activities around such communicative events as reporting, explanation and discussion and exposition. This method makes "genre concept and genre teaching run through the education plan", taking the text of different genres as basis, the discussion of text's cultural context and situational context as the means, the cultivation of students' generic competence as the core, pay attention to "make teachers and students thoroughly understand why the text types change with different communicative purpose, content, audiences and channels" [16], so as to "guide the student to grasp the different communicative purposes and text structures of the text with different genres, make the students realize that text is not only the kind of linguistic constructs, but a kind of social meaningful constructs" through teachers' explicit explanation [17]. The genre-based teaching mode of this school is the unique "genre-based approach-teaching-learning cycle" design by genre theory researchers such as Martin after field investigation and research on the middle and primary schools in Australia, on the basis of confirmation, identification, classification and analysis of "genre".

The teaching model is divided into three stages: Modeling, Joint negotiation of text and Independent construction of the text.

IV. APPlication AND TEACHING PRACTICE OF GENREBASED TEACHING APPROACH IN COLLEGE ENGLISH WRITING TEACHING

Specific procedures of genre-based teaching approach in writing teaching generally are:

\section{A. Demonstration Analysis}

Students discuss the model essay's communicative purpose and the language steps to achieve the goal with emphasis under teacher's questions and inspiration, through collective activity and group discussion, and analyze the deploying method of its macro structure and various structural components, summarize language characteristics of the whole text, as well as the coherence and connection means of the paragraphs.

\section{B. Mutual Consultation}

At this stage, teacher and students make the mutual consultation about the structure and steps of the text to be created, to imitate the construction form the text that has been learned. At this stage, the teacher acts as the copier to write down the results obtained through students' collective 
discussion on the screen or blackboard, so as to make the students digest the genre analysis knowledge that has been learned through practice, to lay the foundation for independent writing in the next phase.

\section{Independent Writing}

At this stage, students can select a topic independently, and create a typical article similar to the model essay independently using the genre that has been learned through the processes of first draft, personally modification, peer assessment, teacher evaluation and editing. At this point, a writing teaching cycle has been basically completed.

According to genre-based teaching method and in combination with the requirements of college English writing teaching, the English composition need to be grasped by college students can be divided into argumentation, exposition, description, narration and practical writing according to genre. Teachers can make the scientific and systematic explanation one by one according to the above five forms using limited hours and the genre-based teaching approach, and require students to master the normative article format of different genre, namely provide them with intuitive model essays of different genre, to facilitate students' direct experience, broad participation and enlightening their thinking, and can also encourage and supervise students to write concrete articles, reflecting the creative learning, interactive learning and collaborative learning in writing class.

\section{AdVANTAGES OF GENRE-BASED TEACHING APPROACH}

Using genre-based teaching approach to carry out writing teaching can make students realize that writing is a kind operable social communicating activity with rules to follow, and a method to understand the objective world and to participate in social activities. Adhere to the idea of "applying what you have learned" and guide students to transform from paying attention to "language knowledge" to "language application". Genre based teaching method pays attention to students' non-language factor errors, which is the writing teaching method emphasizing text structural level and language characteristics according different genre. Exercising writing in combination with model essays of different genre can improve the teaching quality and efficiency more effectively, so that the students have rules to follow in writing to avoid coping with various tests blindly.

Genre-based teaching method can make the students, especially the second language learners of junior or intermediate language level to master a relatively fixed text pattern which can be referred to and depended on, thereby to enhance their confidence in understanding and creation of the text. Use a variety of classroom activities, and guide students shift from "learn to" to "learn well", strengthen the practice of writing output ability, and enhance students' interest in writing. Teachers can not only detailed writing methods and techniques, but also can mobilize the enthusiasm of students through the equal participation between teachers and students; broaden students' vision, increase their information amount, improve their cognitive ability, enhance the language sense, improve writing skills through discussion and reference in order to write the fluent and authentic English.

In the long run, genre-based teaching can develop students' creative thinking ability. When students have grasped the structure and theoretical basis of the genre, they can use the genre skillfully, thus to create the colorful text.

\section{CONCLUSION}

This paper describes the concept of using genre-based teaching approach to improve college English writing teaching from the current teaching condition and the problems of college English writing teaching, and points out its advantages, with the expectation to play a role of inducing the better ones, and arousing the attention and interest of the colleagues in China, so as to apply theory to practice, and improve students' English writing ability.

\section{REFERENCES}

[1] Zhang Zaixin, Wu Hongyun, Wang Xiaoxia, Zhang Junxiang. Main Problems in China's English Writing Teaching [J]. Foreign Language Teaching and Research, 1995, (4):43-49.

[2] Du Jinbang. Reviewing Writing Teaching from Students' English Writing Errors [J]. Foreign Language Teaching, 2001, (2):43-47.

[3] Gan Wenping. Discussion on CET-4 Composition Subject Failures [J]. Journal of Dalian University of Foreign Languages, 2000(2).

[4] Kaplan, Robert. B. 1966. Cultural Thought Patterns [J]. Intercultural Education Language Learning.

[5] Cai Jigang. Study on English and Chinese Writing Contrast [M]. Shanghai: Fudan University Press, 2000.

[6] Enkvist, N. E. 1978. Some Aspects of Applications of Text Linguistics[A]. V. Kohonen and N.E.Enkvist. Text Linguistics Cognitive Learning and Language Teaching[C].

[7] Yang Xiaorong. Reviewing Teaching from Answer SheetComposition Inspection Note of TEAM4 of 1993 [J]. Foreign Language Teaching and Research, 1993(4) .

[8] Swales, J. M. Genre Analysis-English in Academic and Research Settings [M]. Cambridge University Press, 1990

[9] Martin, J. R. A Contextual theory of language[A]. In B. Cope, \&M. Kalantzis (eds). The Powers of Literacy: A Genre Approach to Teaching Writing[C]. New York: Ablex Publishing Corporation,1995.

[10] Bhatia, V. K. 1993. Analyzing Genre: Language Use in Professional Settings. London: Longman..

[11] Qin Xiubai. "Genre Analysis" Introduction [J]. Foreign Languages, 1997(6).

[12] Zhang Yuanrong. Style Analysis, Register Analysis and Genre Analysis of Text [J]. Shandong Foreign Language Teaching, 1997(3)

[13] Fang Yan. Discussion on Genre [J]. Foreign Languages , 1998(1)

[14] Bhatia, V. K. 1993. Analyzing Genre: Language Use in Professional Settings. London: Longman

[15] Martin, J, R., 1992. English Text: system and structure. Amsterdam: Benjamins

[16] Hammond J, B Derewianka Genre. In R Carter, and D Nunan (eds). A Cambridge Guide to Teaching English to Speakers of Other Languages [C]. Cambridge University Press,2001

[17] Hammond J. An Overview of the Genre-based Approach to the Teaching of Writing in Australia[J]. Australia Review of Applied Linguistics. 1987, 10(2): 163-81 